American Journal of Qualitative Research

June 2021, Vol. 5 No. 1, pp. 44-66

https://doi.org/10.29333/ajqr/10792

(C) 2021 AJQR. http://www.ajqr.org
AMERIGAN

JOURNAL OF QUALTATIVE

RESEARCH

ISSN: $2576-2141$

\title{
Low Job Satisfaction as A Lived Experience for Experienced Middle School Teachers in Rural Tennessee: A Phenomenological Study
}

\author{
Shayla D. Hawes ${ }^{1}$ and Timothy R. Nelson \\ Liberty University, USA
}

\begin{abstract}
The purpose of this transcendental phenomenological study was to understand the lived experiences of rural experienced middle school teachers in Tennessee with low job satisfaction. Urie Bronfenbrenner's ecological systems theory (EST) was the theoretical framework guiding this study. EST is composed of five environmental systems: microsystem, mesosystem, exosystem, macrosystem, and chronosystem. This study included participation from 10 experienced teachers with 5 or more years of teaching experience who demonstrated low job satisfaction in Tennessee according to the results of a questionnaire given prior to conducting the study. The central research question guiding this study was, what are experienced middle school teachers' perceptions of job satisfaction as a lived experience in rural Tennessee? The four sub questions were designed to investigate how teacher workload, collegial experience, administrative leadership and support, and student behavior impact job satisfaction. Data for this study were collected through individual interviews, an online focus group interview, and a reflective journal, and produced four major themes: (a) unrealistic expectations, (b) middle school environment, (c) students, and (d) middle school teacher challenges. The findings revealed participants' perceived administrators and policy makers had unrealistic expectations on their teachers due to being disconnected from their teachers. The findings also indicated participants' environment at the middle school level was challenging as they dealt with the basic needs of students before educating them. Participants expressed that collegial support was vital to the profession and that they loved teaching but had negative perceptions about the challenges they often encounter on the job.
\end{abstract}

KEYWORDS: Low Job Satisfaction, Middle Schools, Rural Schools.

Researchers note one of the most important and influential professions in society is the teaching profession as teachers play a significant role in shaping the nation's future and developing adolescents into citizens who can contribute to society (Sahito \& Vaisanen, 2017; Skaalvik \& Skaalvik, 2018). Scholars suggest that despite being a rewarding profession and a valuable asset to an advancing society, teaching has multiple challenges (Huang et al., 2019; Przybylska, 2016; Sahito \& Vaisanen, 2017; Skaalvik \& Skaalvik, 2018). Teachers in middle schools encounter problems that differ from those in elementary and high schools (Mee \& Haverback, 2014). In addition, rural schools deal with problems that are different from those in urban schools (Hos et al. 2019; Wieczorek \& Manard, 2018; Zuckerman et al., 2018). Sometimes the challenges middle

${ }^{1}$ Correspondent Author E-mail: scarew@liberty.edu 
school teachers encounter can take a toll on them and eventually lead them to experience low job satisfaction, which in turn may impact their job-related experiences (Skaalvik \& Skaalvik, 2015).

Teacher job satisfaction has been a growing concern in the field of education within the last decade (Liu et al., 2016; Skaalvik \& Skaalvik, 2010). Within rural school districts, obtaining highquality teachers and retaining them has been an issue. Scholars have explored what contributes to teacher job satisfaction and what motivates high quality teachers to remain in the profession (Lowe et al., 2019; Prout et al., 2019); however, there is a need to examine low job satisfaction among teachers (Gulosino et al., 2016). The study of teacher job satisfaction connects to Urie Bronfenbrenner's (1976, 1979) ecological systems theory (EST) as it deals with how an individual's development is influenced by his or her environment.

Many scholars have highlighted characteristics of experienced teachers who demonstrate high levels of job satisfaction and why they stay in the profession (Cansoy \& Parlar, 2018; Evers et al., 2017; Gray et al., 2017; Skaalvik \& Skaalvik, 2018). Researchers have also identified causes of low levels of job satisfaction among teachers (Gius, 2015; Gkolia et al., 2014; Huang et al., 2019; King, 2017; Przybylska, 2016; Skaalvik \& Skaalvik, 2015). Unfortunately, there is little research on middle school teachers and rural schools. Due to the focus on giving a voice to rural experienced middle school teachers who have low job satisfaction, this study will add to the literature by providing a unique perspective on teachers with low job satisfaction. In addition, administrators, novice teachers, school board members, and federal government officials may benefit from the findings from this study of experienced middle school teachers' lived experiences with low job satisfaction in rural Tennessee.

The purpose of this transcendental phenomenological study was to understand experienced middle school teachers' lived experiences with low job satisfaction in rural Tennessee. Low job satisfaction was defined as the negative feeling an individual has toward his or her job (Aldridge \& Fraser, 2016; Banerjee et al., 2017; Okeke \& Mtyuda, 2017; Spector, 1997). Job-related experiences were defined as experiences individuals have on the job that contribute to high or low levels of job satisfaction (Ford et al., 2017; Skaalvik \& Skaalvik, 2015).

\section{Literature Review: Theoretical Construct}

In developing EST, Urie Bronfenbrenner (1976, 1979) studied human development and how an individual's environment plays a significant role in his or her development. Bronfenbrenner $(1976,1979)$ sought to understand the way individuals developed and he believed it was important to observe their behavior in their natural settings or environment while interacting with familiar people such as family, friends, and colleagues. Bronfenbrenner identified these systems as microsystem, mesosystem, exosystem, macrosystem, and chronosystem. Within each ecological system, individuals experience transitions in their roles or settings throughout their lifetimes. When describing the transitional roles of an individual, roles can have an impact on how an individual is treated, behaves, thinks, and feels (Bronfenbrenner, 1976, 1979). When studying the job-related experiences of rural, experienced teachers in Tennessee with low job satisfaction, it is important to recognize the teachers as individuals whose environment is the school setting (Burns et al., 2016; Sapkova, 2014; Smith et al., 2017). As previously mentioned, Bronfenbrenner $(1976,1979)$ argued early in the development of the EST that research concerning human development needed to be focused more on the immediate setting of an individual and how it impacts his or her own development (Rosa \& Tudge, 2013).

When examining job satisfaction among experienced teachers, it is important to consider the environment in which they live and work. According to Smith et al. (2017), the social agents 
in the microsystems of a teacher's environment consist of family, social groups, students, and school faculty. Disruptive students and administrative leadership contribute to low job satisfaction among teachers (Thibodeaux et al., 2015). Furthermore, rapport with other teachers can contribute to teachers experiencing low job satisfaction in the teaching profession (Skaalvik \& Skaalvik, 2018). If collegial experience with other teachers is negative for a teacher, he or she may develop a negative attitude toward his or her profession over time (Evers et al., 2015; Evers et al., 2017; Graham, 2015).

The mesosystem deals with the relationships between the social agents of an individual. Within this system, a teacher's experience with family may be connected to his or her experience at school (Smith et al., 2017). If a teacher has a negative experience at home with family, he or she may leave with negative feelings (Liu \& Cheung, 2015). Furthermore, conflict between family and work can be draining and exhausting for teachers. Dealing with this type of interaction between microsystems can negatively affect the performance of teachers when they are at home or school. Skaalvik and Skaalvik (2015) also pointed out that when teachers experience low job satisfaction, they may be less sensitive to the individual needs of students.

The exosystem involves the connection between an individual and his or her environment. The environment of teachers can be significantly impacted by administration, the school system, and the federal government (Smith et al., 2017). Teachers in a school setting may not have direct contact with administrators on a daily basis; however, they can still be influenced by the decisions made by administrators, such as scheduling (Pogodzinski, 2014). Teachers may not see school board members or the superintendent directly, but they can be impacted by decisions made by these educational stakeholders.

In EST, the macrosystem is a sociocultural environment which consists of the microsystem, mesosystem, and exosystem. Within this system, the economy, political realm, and sociocultural status of an individual affects an individual's development (Bronfenbrenner, 1976, 1979; Nand, 2017). There are multiple cultural components - politics, cultural values, or the economy - that influence an individual's development (Wieczorek \& Manard, 2018; Zuckerman et al., 2018). In the state of Tennessee, there are multiple rural school districts. Components in the macrosystem affect rural communities differently than urban communities. For instance, rural schools receive less funding from the federal government than do urban schools (National Education Association [NEA], 2017). Rural school teachers also face the challenge of a lack of resources (NEA, 2017). Another challenge that rural educators face is a lack of student motivation. As a result of a lack of resources, teachers' classroom instruction may be impacted (Azano \& Stewart, 2015).

The chronosystem consists of the microsystem, mesosystem, exosystem, and macrosystem, which all occur at various times throughout the lifespan of an individual (Nand, 2017). Major events that impact an individual's development occur in this system. Teachers may experience marriage, divorce, having children, the loss of a family member or friend, transferring schools, or change in educational position at some point in their careers.

\section{Job Satisfaction}

A variety of factors have been found to influence the job satisfaction of teachers. According to Liu et al. (2016), employees are more likely to be creative, productive, and remain in their profession longer when they are highly satisfied with their jobs. Some causes of teachers being dissatisfied consist of a lack of opportunities for advancement, a lack of encouragement and recognition, stress, a non-supportive work environment, and a lack of work-life balance (Sahito \& Vaisanen, 2017). Spector (1997) stated there was a positive correlation between job satisfaction 
and an organization's success, and that job satisfaction helps attract and retain teachers. Dou et al. (2016) explained that teachers who become disengaged have given up commitment and put little effort into their work. One of the negative effects of low job satisfaction in an organization is chronic absenteeism. Studies have shown that chronic absenteeism in teachers has a negative impact on schools, particularly on student learning (Balwant, 2016; Kronholz, 2013; Sezgin et al., 2014; Shapira-Lishchinsky \& Raftar-Ozery, 2016). Researchers have noted if teachers are not committed to coming to class, students' commitment to class may decrease and cause student achievement to decline (Balwant, 2016; Sezgin et al., 2014).

\section{Rural Education}

Although rural communities are often seen in a positive light, they do face challenges such as poverty, economic changes, demographic changes, and educational accountability (De Klerk et al. 2021; Wieczorek \& Manard, 2018). These environmental challenges affect rural communities, including rural schools. As a result of the challenges rural regions face, teachers can often run into difficulties educating children from a rural area. Wieczorek and Manard (2018) stated that schools in rural communities are influenced by elements in the environment which include poverty, accountability, involvement from the community, educational policies, and financial constraints. According to the NEA (2017), rural school districts serve over $40 \%$ of the nation's students, but only $22 \%$ of federal education funding is provided for these school districts. In addition to the financial constraints placed on rural schools, educational policies also affect these rural schools (Zuckerman et al., 2018). Many of these policies emphasize holding teachers accountable for what is taught and preparing students to be college and career ready upon graduating (Zuckerman et al., 2018). For instance, Parsley and Barton (2015) pointed out that the ESEA has encouraged those in the education system in America to focus on improving in a variety of ways such as providing high-quality learning experiences early on for students, establishing accountability and support systems for low-performing schools, implementing rigorous standards that ensure students are college- and career-ready, and providing high-quality teachers. Although retaining high-quality teachers is a challenge for any school system, it is especially difficult for rural school districts (Parsley \& Barton, 2015).

\section{Middle School Teachers}

Middle school teachers work in a unique environment as they work with early adolescent students in a challenging setting (Huang et al., 2019; Przybylska, 2016). Im et al. (2016) stated that middle schools consist of students in Grades 6-8 who are typically characterized by rapid emotional, cognitive, and biological changes the adolescents experience as well as changes in their school, family, and peer relationships. Within the teaching profession, there are multiple job-related responsibilities teachers are expected to perform (Glover et al., 2016). Along with typical teaching responsibilities, middle school teachers implement student discipline, maintain records, and provide coverage for teacher shortages (Desouky \& Allam, 2017). These teachers may coach sports or advise clubs, all of which typically take place before and after school (Bureau of Labor Statistics, 2018; NEA, 2017). Further, many teachers work in summer programs, take graduate courses to maintain certification, or attend mandatory professional development during the summer break. 


\section{Factors in Teacher Satisfaction}

Research has found a variety of additional factors that contribute to job satisfaction. Compared to urban teachers, one of the major challenges rural educators face is lower salaries (Tang et al., 2018) and these discrepancies can be as much as $\$ 10,000$ annually (Tennessee Education Association [TEA], 2019). Rural teachers experience increased workload because there are fewer teachers to share additional roles compared to larger, urban schools (Johari et al., 2018). Problems with student behavior can compound these frustrations (Gray et al., 2017). While a smaller salary and increased workload are often associated with lower job satisfaction, job satisfaction can be increased by stronger collegial experiences with other teachers (Thibodeaux et al., 2015), positive experiences with supportive parents (Benner et al., 2016), and a supportive administrative staff (Pogodzinski, 2014).

Ford et al. (2017) stated that within the last few years, job satisfaction among teachers has continuously declined. Recent studies have revealed multiple causes of low levels of job satisfaction among teachers, especially experienced rural educators (Aldridge \& Fraser, 2016; Benoliel \& Barth, 2017; Bogler \& Nir, 2014). Although studies (Gray et al., 2017) have been conducted with elementary and high school teachers regarding job satisfaction and components that contribute to them remaining in the profession, a gap in the literature exists because the job satisfaction of middle school teachers from rural schools have not been studied.

\section{Case and Methodology}

A transcendental phenomenological design (Creswell, 2013; Moustakas, 1994) was used to understand low job satisfaction as a lived experience for experienced middle school teachers in rural Tennessee. These participants came from three middle schools in two rural school districts. Student diversity varied across the school districts with most of the students being White (81\% and $93 \%$ ) and the middle school student population of around 1,000 students. Between 45 and $75 \%$ of students receive free and reduced lunch.

Upon approval from the Institutional Review Board, teachers were sent a consent form which was collected prior to the first interview with each participant. Purposeful sampling was implemented to recruit participants who were experienced middle school teachers and self-reported as experiencing low job satisfaction. Although attempts were made to increase the diversity of the sample, all 10 participants were White middle school educators with five or more years of experience who self-reported as experiencing low job satisfaction. Paul E. Spector's (1997) Job Satisfaction Survey (JSS) was used to determine participants who met the criteria of experiencing low levels in job satisfaction. The JSS contains 36 items, which are measured from 1 (strongest disagreement) and 6 (strongest agreement). High scores indicate job satisfaction and low scores indicate low job satisfaction. Before being scored, items that are negatively worded must be reversed. Spector (1999) stated the cut score for the JSS is broken into three categories. A score of 144-216 shows high job satisfaction and a score of 36-108 indicates low job satisfaction. A score of 108-144 reveals feelings of doubt concerning the job. Coworkers, job conditions, nature of the work, organization, policies and procedures, communication, appreciation, personal growth, pay, fringe benefits, recognition, supervision, promotion opportunities, and security are job satisfaction facets of the JSS measures (Spector, 1997).

In order to understand the meaning and the nature of the participants' experiences (Moustakas, 1994) the 10 educators participated in individual interviews, an online focus group interview, and a reflective journal (Todd-Gibson, 2017). To protect the confidentiality of 
participants, pseudonyms were provided and used throughout the study rather than using teachers' actual names. Schools and school districts were not mentioned in the results to further protect participants' confidentiality. See Table 1 for information regarding gender, years of experience, and participants' location of teaching experience.

Table 1

Teaching Experience of Participants

\begin{tabular}{lcccc}
\hline Name & Gender & $\begin{array}{c}\text { Years of } \\
\text { experience }\end{array}$ & Grade(s) taught & School level experience \\
\hline Annie & Female & 14 & 6 & Middle only \\
Carol & Female & 22 & 8 & Elem. \& middle \\
Denise & Female & 30 & $6-8$ & Elem. \& middle \\
Joe & Male & 13 & 8 & Elem. \& middle \\
Kelly & Female & 21 & 6 & Elem. \& middle \\
Kevin & Male & 15 & 8 & Elem. \& middle \\
Mary & Female & 13 & $6-8$ & Elem. \& middle \\
Olivia & Female & 19 & $7-8$ & Elem. \& middle \\
Suzie & Female & 6 & 6 & Middle only \\
Veronica & Female & 21 & 8 & Elem. \& middle \\
\hline
\end{tabular}

\section{Data Collection}

Interviews were audio-recorded and stored electronically on a password protected computer. To increase each participant's comfort, participants were interviewed individually at their schools. Participants were asked to introduce themselves and answer a premade list of questions. Some of the questions were "What is your experience with administrative leadership?" "What is your experience working with colleagues?" "Why did you choose to teach at the middle school level?" "What is your experience with students, particularly disruptive students" "What is your experience with workload as a teacher?" The interviews were semi-structured and allowed follow up questions for clarity or additional information.

The online focus group interview was conducted online as participants remained at their schools and discussed the interview questions. According to Woodyatt et al. (2016), when compared to in-person interviews, online focus groups have equal potential to gather high-quality information. Online discussion forums also allow participants to share their thoughts and feelings anonymously (Sroufe, 2013). Using an online discussion forum to conduct the focus group interview was also beneficial for this study as participants resided in distant locations in Tennessee. Anonymity was secured for participants by giving pseudonyms for login names. Some of the questions were "What do you think is the most difficult aspect of being a rural middle school teacher in Tennessee?" "What do you wish educational stakeholders outside the classroom (i.e., parents, administrators, school board members, and policymakers) knew about your job?" "What role do standards and standardized assessments play in your profession and how you feel about teaching?" "What would you like to add to previous comments or statements made in this online focus group interview?"

A reflective journal was a beneficial method of data collection in this study as journals encourage reflective thoughts (Lindroth, 2014). Participants responded to four journal prompts and were viewable only by the researchers. Some of the prompts were "If a visitor assisted you at school 
for a day, what could they expect?" "How do you manage your workload as a teacher" "How do you relate to colleagues, students, administrators, and parents?"

\section{Data Analysis}

After conducting interviews with participants individually and the online focus group interview, the interviews were transcribed using Weloty transcription services. After receiving the reflective journals electronically, they were uploaded to Nvivo 12. Over the course of 2 weeks, data from interviews and journal entries were attentively reviewed. Significant statements, words, and phrases were highlighted and categorized into individual nodes. Using NVivo 12's memoing feature, memos were used to connect thoughts and ideas about the nodes and identify relationships between the nodes. NVivo 12's word frequency feature was used to assemble 100 of the most frequently used words in all data collection methods for this study. Figure 1 displays the results of the word frequency feature.

\section{Figure 1}

Word Frequency Chart of Recurring Words as Indicated Using NVivo 12

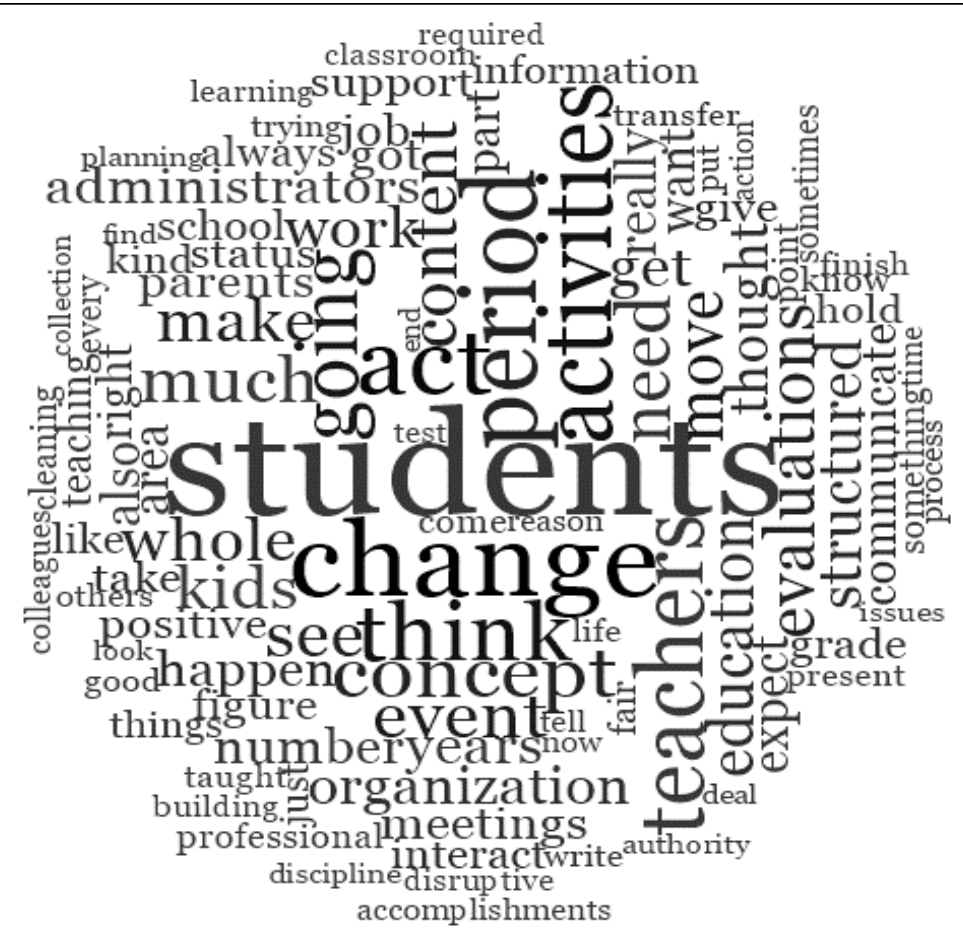

Codes were identified from teachers' responses and categorized to aid in presenting themes. Four major themes emerged from the data to present the narrative of the lived experiences of experienced middle school teachers in rural Tennessee.

\section{Theme 1: Unrealistic Expectations}

The first major theme identified was unrealistic expectations. According to the participants, these expectations came from administrators, parents, central office employees, and policymakers. 
See table 2 for subtheme and codes, along with the frequency of times that the top three codes for each subtheme were found among the three data collection methods.

Table 2

Theme 1: Unrealistic Expectations

\begin{tabular}{ll}
\hline \multicolumn{1}{c}{ Subtheme } & \multicolumn{1}{c}{ Code (frequency) } \\
\hline Administrators and policymakers & Disconnect (13) \\
& Expectations (8) \\
& Lack of support (6) \\
& \\
Disconnect & Transitions (10) \\
& Policies (10) \\
& Decisions (5) \\
\hline
\end{tabular}

\section{Administrators and Policymakers}

Two major educational stakeholders discussed by participants were administrators and policymakers, which collectively emerged as a subtheme. When describing administrators and policymakers, participants used the word disconnect which was noteworthy. This word was specifically used when participants described how they related to their administrators. Multiple participants stated administrators typically address individual issues or concerns in front of the entire faculty, leaving some teachers to question what they have done wrong. In her interview, Suzie stated,

I don't feel like if I'm doing something wrong in my classroom, my administrator will come and talk to me. Instead, they make a blanket statement at faculty meetings or in a weekly email instead of addressing me personally and so I never know what exactly I'm doing good on or what I need to improve on.

In her journal response, when asked how she relates to administration Veronica wrote,

Another thing that has made it difficult to relate is due to the lack of correction of individual teachers for misconduct. Everything that happens in our building is disciplined with a blanket statement to the entire faculty. This makes it difficult to trust administration because you are always disciplined for things that are not necessarily your problem.

\section{Disconnect}

In addition, some participants went beyond administration and discussed policymakers at the federal level and again used the word disconnect. These educational stakeholders often become disconnected and less likely to relate to their teachers as they seem to forget what it is like in the classroom and the expectations teachers are required to meet. The longer an educational stakeholder is away from the classroom, the more evident the disconnect becomes to teachers, as Olivia stated in her interview: 
I think the longer that they are away from the classroom the more prevalent that is. Not only that but it's just strange in that it's almost like when they come out of the classroom, they literally take that classroom teacher hat off and then they put on the administrative hat. They start seeing things completely different. Their perspective on things is different, which is understandable because they're in a position of administration at that point; however, it's also important to be able to relate to where your teachers are.

Denise also noted in her journal the unrealistic expectations put on teachers:

Administrators should also stop making extra work for teachers that is of no benefit except to make them look good. Administrators, like many others, need to be able to remember what it is like to be in the classroom working with limited resources and funding!

During the online focus group, teachers were asked what they wish all educational stakeholders knew about their job. Carol explained that she wants understanding and support for stakeholders in education:

Parents need to understand the importance of education for their kids and help raise them to be respectful and behave in order to learn. Administrators need to understand my lessons may not fit into their rubric. Every class period is not a simple intro, activity, and closure. Life happens and things have to be dealt with regardless of standards, like counseling kids and dealing with peer issues. The school board needs to fully fund all classrooms. I need curriculum to teach by and test question banks to use and I have none of that.

Mary added to Carol's statement by sharing the various roles teachers fulfill in addition to being an educator:

I wish they knew the real demand put on teachers. We are truancy officers, child welfare checkers, moral supporters, mentors, advisors, and then educators.

\section{Theme 2: Middle School Environment}

The second major theme to emerge from the data was middle school environment. The environment of a middle school is a unique setting as teachers work with young adolescents and encounter many challenges (Huang et al., 2019; Przybylska, 2016; Waterman, 2013). The three subthemes under the theme of middle school environment were restrictions, colleagues, and resources (see Table 3). 


\section{Table 3}

Theme 2: Middle School Environment

\begin{tabular}{|c|c|}
\hline Subtheme & Code (frequency) \\
\hline \multirow[t]{3}{*}{ Restrictions } & Strict Schedule (9) \\
\hline & Limited lunch (7) \\
\hline & Limited restroom breaks (5) \\
\hline \multirow[t]{3}{*}{ Colleagues } & Family (15) \\
\hline & Support (13) \\
\hline & Trenches (7) \\
\hline \multirow[t]{3}{*}{ Resources } & Personal spending (13) \\
\hline & Lack of supplies (8) \\
\hline & Curriculum (7) \\
\hline
\end{tabular}

\section{Restrictions}

In this theme, middle school was emphasized as teachers described their lived experiences at their middle schools rather than the environment of an elementary school or high school. The responses of participants helped create a clear image of their work environments. Teachers frequently mentioned ways in which they were restricted such as having a tight schedule. An example of this was provided in Veronica's journal entry:

Lunch is about 25 minutes where the assistant would have to help me take and pick up students from the cafeteria. One only ends up with approximately 20 minutes to actually eat lunch. This time is also the only real time to collaborate or socialize with peers in which one teaches with.

In her journal, Olivia echoed the same experience of having a restricted schedule:

Daily, I have to monitor the restrooms at my scheduled time that we have worked out among our team of four. Because I am at the end of the hall, another teacher or staff member has to watch my classroom while I am supervising the restroom break.

\section{Colleagues}

The way participants described the colleagues they closely worked with as supportive and important indicated that colleagues were essential in their work environment even though at times there could be unfavorable interactions with other colleagues they were not as close to in their middle schools. As Joe stated

Honestly, that's one thing that keeps me here, just to be completely honest. A lot of the teachers work with you and help you and it's a good experience.

Although the workload and responsibilities of teachers can be overwhelming at times, teachers work together to accomplish these tasks. Participants described a familial relationship with their colleagues and how they face challenges within their schools and education together. Veronica also emphasized the importance of collegial support: 
The colleagues in this building and in this setting are what push the majority of the people, I think, to continue with the job. If it weren't for that, I don't know how you could continue on. . . . Our colleagues, our hallway is very helpful to each other. We'll pick up pieces for each other when something happens in personal lives or whatever.

\section{Resources}

In addition to restrictions in their middle school environments, participants discussed how their work environments were impacted in a rural setting. Teachers frequently mentioned a lack of access to resources, which aided in the development of resources as another subtheme. Due to not being provided enough money for classroom supplies, teachers are often forced to use their own money for supplies and materials they need for the classroom. In his journal, Joe described his experience with a lack of resources:

I would like more support with resources, or monies. My wife and I are spending approximately \$1,000 together, maybe more, a year for classroom supplies.

For Carol, it is not just classroom supplies she spends money on, but also curriculum:

I have nothing. I have spent over $\$ 500$ of my own money on Teachers Pay

Teachers up to this point in the year and I'm not even done.

\section{Theme 3: Students}

The third major theme discovered from the data was students. At the center of NVivo's word frequency chart was students. Behavior was identified as a subtheme due to the responses from participants about various behaviors demonstrated at the middle school setting (See Table 4).

\section{Table 4}

Theme 3: Students

\begin{tabular}{ll}
\hline Subtheme & Code \\
\hline Behavior & Disruptive (13) \\
& Socially unstable (12) \\
& Defiance (3) \\
Troubled lives & Lack of parental involvement (7) \\
& Drugs and homelessness (4) \\
& Self-harming (3) \\
\hline
\end{tabular}

\section{Behavior}

One of the factors that impact a teacher's job satisfaction is the behavior of disruptive students, which was one of the subthemes for the theme of students. Some of the disruptive behaviors that teachers have complained about concerning students include a lack of self-control, inability to manage emotions, and a lack of respect for teachers and peers (Oberle \& Schonert- 
Reichl, 2015; Skaalvik \& Skaalvik, 2015; Waterman, 2013). Although participants were asked to discuss students in the interview and online focus group interview, teachers provided candid responses in their journal entries. Kelly wrote:

We do have quite a few students this year that have major discipline issues. In our school, we do not really have a means to deal with these students. We need a behavior classroom where these students can go if there are issues that repeatedly occur.

When journaling what a visitor could expect if assisting her, Suzie wrote,

While the visitor would see mostly good, they would also see minor student behavior problems. He or she would see me standing over one student so that he would complete his independent work. He or she would see me quieting my talkative kids and telling them to get back to their work. The visitor would see students who can't sit still and move 24/7. The visitor would see my frustration come out with a student who constantly wants to pick a fight with another student.

\section{Troubled Lives}

Another subtheme that was developed from the data was troubled lives. This developed into a separate subtheme as students' behavior often reflected their troubled lives according to responses from participants. Middle school students often experience emotional, cognitive, and biological changes in a short period of time (Im et al., 2016). Annie described the challenges she sees students face, pointing out how the issues students face today are different than they were years ago and how those problems affect her ability to teach:

Over the 20-odd years I've been teaching, I have seen the behavior problems escalate from students who would talk or pass notes to issues such as self-harming, tobacco use, possible drug use.

Denise shared the same point of view:

When I started 30 years ago, you didn't have kids coming in starving. You didn't have kids that were sleeping in a motel that were sleeping on the floor.

\section{Theme 4: Middle School Teacher Challenges}

The fourth major theme that developed from the data was middle school teacher challenges. Responses from participants indicated they continued to work after school and on weekends, which goes outside the work environment at teachers' middle schools. Three subthemes that emerged from the data were overwhelming workload, hours and pay, and roles (see Table 5). 


\section{Table 5}

Theme 4: Middle School Teacher Challenges

\begin{tabular}{ll}
\hline Subtheme & Code \\
\hline Overwhelming workload & Grading (14) \\
& Planning (12) \\
& Analyzing data (8) \\
Hours and pay & Long (15) \\
& Low salary (14) \\
Roles & After school (10) \\
& Parents (8) \\
& Counselors (7) \\
& Police officers (3) \\
\hline
\end{tabular}

\section{Overwhelming Workload}

Overwhelming workload was developed as a subtheme under the major theme of middle school teacher challenges. When describing what job-related responsibilities, she has, Suzie discussed what she does in addition to teaching:

I do the yearbook, so that takes a lot of planning for pictures for yearbook. Planning what the pages are going to be, making sure the students get included in the pages and their portraits. Dealing with sports pictures, dealing with money; that's probably one of the biggest responsibilities with yearbook is the money aspect of it.

Olivia also takes on an additional responsibility aside from teaching as she is a sponsor for the entire eighth grade class:

I'm also an eighth-grade sponsor where we are involved with fundraising and we work toward having an end-of-the-year trip and trying to make that last year for our eighth-grade middle school students something that they remember before they go on to the high school.

\section{Hours and Pay}

It was evident from participants' responses that they believed they put in long hours for their work and received little pay compared to the work they do. Due to the demanding workload placed on teachers and the time they have to complete their work, teachers frequently spend many hours working outside of the school day (Johari et al., 2018). Another example of continuous hours spent on completing job-related tasks was revealed in Joe's journal:

The easiest part of my job is when I am teaching. The true work begins at 3:10 every day. In addition, we are expected to come up with a homeroom activity, call parents (if students are in danger of failing), prepare for any school activity that is coming up, assessing students daily, and looking at data from every test that they are given trying to figure out how I can help those who need catching up with the class. 
Veronica further revealed in her journal that her children often need her attention and help for a variety of tasks at home and that she is left with no choice but to wait until her children are in bed before she can focus on her job-related workload:

I find that many times it is not until after my children are in bed that I am able to finish the work that I have.

Some teachers shared that the pay scale does not amount to the education they received. When discussing teacher salaries during the online focus group interview, Kelly stated,

And we do not pay experienced teachers for time invested in the system. With the number of degrees, I have and the years I attended college, I could've been a doctor by now.

Denise then shared

I could make just as much without a degree as what I make here . . 30 years and I finally hit $\$ 50,000$.

\section{Roles}

Roles emerged as a subtheme due to teachers' descriptions of a variety of roles they fulfill. Many of the themes and subthemes seemed intertwined as they showcased the lived experiences at the middle school level. In her journal response, Veronica shared how having to supervise student behavior sometimes takes away the focus of educating students:

Between each class period teachers are responsible to monitor both hallways and restrooms in an attempt to stop illegal activities as JUULing [use of an electronic cigarette]. If a visitor helped out in our school and in my classroom, they would feel as if they are policing student activity rather than molding minds of young people.

Teachers also described how they frequently must take on the role of a parent or counselor before they can educate the students. When discussing students' troubled lives and the lack of parental involvement, Denise stated

We have lots of that and just coming in and the situations that the parents are not parents anymore. So therefore, we just can't be educators anymore. We have to be parent and educator, which is really sad.

\section{Primary Research Question}

The primary research question for this study was aimed to fill in a gap in the existing literature surrounding teacher job satisfaction and, more specifically, what are the lived experiences of experienced middle school teachers in rural Tennessee? Although the participants love teaching, they revealed that their perceptions of the job were negative, overall. An example of this was evident in Joe's journal response regarding what a visitor might expect in his classroom: 
They would see a frustrated teacher that has to cover 90 minutes worth of material in 60 minutes. . . I I do all I can to help them be successful in life and academics, but some days I feel that is an impossible task for me.

Many of the participants perceived there were unrealistic expectations from educational stakeholders. Kelly shared the following during the online focus group interview:

I wish they had a clue about kids' ability levels. How are we supposed to teach in a classroom of 25 students ranging from 1st percentile to 99th?

Participants frequently mentioned their interactions with administrators as a critical facet of their experience. Mary wrote:

Relating to administrators poses problems at times. I feel that there is no reciprocal accountability. Admin asks for many things to be done, but time/resources to carry out the demands are rarely given.

Although there are many challenges presented to teachers on a daily basis, the support of colleagues was found to be a positive factor. Veronica believed colleagues hold schools together in the midst of challenges teachers often encounter:

So, I think it is the colleagues, or the people in the trenches as I like to call it, that holds the glue. It's the glue that holds the building together. If we didn't have each other I don't think we could make it. That is the strongest part, is the relationships you build with your coworkers to be able to surpass all the things that don't make sense in this job.

Some of the teachers expressed that they consider their colleagues more like a family due to working closely together. This was evident in Kelly's journal entry:

I truly love my work family in my grade. Most of us eat lunch together every day. A lot of us are also friends outside of school as well. We often do things together on the weekends. If someone is having a tough day, the other teachers will rally around us to make it better. You can depend on every teacher in my grade to have your back with personal and school issues.

\section{Discussion}

This study served to describe the lived experiences of experienced middle school teachers in rural Tennessee. Participants' experiences were recorded through interviews, an online focus group interview, and reflective journals. Overall, teachers expressed that they loved teaching and making a difference in students' lives, but they strongly disliked the job-related aspects that impact their classroom. Findings from this study confirmed and added to empirical research on the topic of teacher job satisfaction and aspects of the teaching profession that impact job satisfaction. Empirical research has identified a variety of components that impact teacher job satisfaction. Some of the major aspects in the teaching profession include workload, work environment, 
collegial experience, administrative leadership and support, and student behavior. This study supported and added to some of these components, but also diverged from previous research.

This current study validated the fact that job satisfaction decreases as classroom stress increases (Troesch \& Bauer, 2017). Participating middle school teachers emphasized the importance of school administrators relating to their teachers so they can properly support and encourage teachers when needed. Previous research has indicated the time in which teachers are expected to complete assigned tasks from administrators and other educational stakeholders plays a significant role in job satisfaction as well as the physical and mental health of teachers (Skaalvik \& Skaalvik, 2015; Waterman, 2013; Yu et al., 2015). The responses from teachers corroborate these observations as many teachers explained that the time they have to perform job-related tasks is not enough.

This also confirms previous research on rural education and the issue of limited resources for rural schools (NEA, 2017; Wieczorek \& Manard, 2018). All of these middle school teachers expressed how limited resources restrict the learning environment in their classroom and explained that they do not always have the materials and supplies they need. Furthermore, they revealed most of the materials and supplies they do have are paid for with their own money.

One major divergence from previous research was teachers' attitudes regarding their contribution to their schools while self-reporting as experiencing low job satisfaction. Previous research has shown that teachers who experience low job satisfaction are more likely to become disengaged in the teaching profession, put forth little effort into performing job-related responsibilities, and give up commitment altogether (Banerjee et al., 2017; Dou et al., 2016). Although teachers in this study self-reported as experiencing low job satisfaction, they also expressed their love for teaching and working with students. Their lack of satisfaction toward their jobs was directed more toward multiple aspects of their careers such as workload and work environment, administrative leadership and support, and dealing with student problems not related to the classroom.

Within the school environment teachers have many interactions with their colleagues. Collegial experience can have a negative impact on job satisfaction if colleagues are disrespectful, not supportive, or complain too much (Cucchiara et al., 2015; Pogodzinski, 2014; Rankin, 2017). This study was diverse from previous research as teachers generally spoke highly of colleagues and emphasized the importance of collegial support in their profession.

Previous research has shown that the student behaviors teachers often complain about consist of a lack of self-control, lack of respect, and the inability to deal with emotions (Oberle \& Schonert-Reichl, 2015; Skaalvik \& Skaalvik, 2015; Waterman, 2013). Teachers mentioned some of the behaviors they deal with from students also included excessive talking and a lack of effort put forth on assignments. Responses from these middle school teachers corroborated with previous research on student behavior, but they also added to literature concerning the connection between student behavior and their troubled lives at home (Waterman, 2013).

The theoretical framework guiding this study was Bronfenbrenner's $(1976,1979)$ EST, which is focused on human development and how the environment of an individual can impact one's development. An individual's interactions with the social agents in one's immediate environment (microsystem) can affect one's development. The findings from this present study diverged from previous research (Skaalvik \& Skaalvik, 2018; Thibodeaux et al., 2015) as teachers expressed that they have positive relationships and interactions with students and other teachers.

Regarding the mesosystem, responses from teachers supported and added to previous research. Some teachers expressed that they struggle with balancing work and family as they often take work home. Although previous research has shown teachers may be less sensitive to student 
needs if they experience low job satisfaction (Skaalvik \& Skaalvik, 2015), findings from this study indicate that teachers are sensitive to the needs of their students as they described the various roles they fulfill to help take care of their basic needs. Teachers shared that before they can educate students, they must be a parent, counselor, and nurse among other roles due to students having troubled lives at home. The exosystem consists of outside agents concerning educators include administration, the school district, and federal government (Smith et al., 2017). Although teachers may not directly interact with administration, the central office, or the federal government, the decisions made from these agents can impact a teacher's immediate environment and individual development.

In the macrosystem, environmental components such as the economy, politics, and socioculture can impact the development of an individual (Bronfenbrenner, 1976, 1979; Nand, 2017). The development of teachers in rural school areas is often affected by components such as politics, the economy, cultural values, and poverty (Wieczorek \& Manard, 2018; Zuckerman et al., 2018). Furthermore, rural schools often face the challenge of limited funding and a lack of resources, which impacts rural teachers' environment (Azano \& Stewart, 2015; NEA, 2017). This study corroborated previous research as teachers explained they have limited resources for their classrooms and that due to a lack of funding, they often have to spend their own money on materials and supplies.

\section{Practical Implications}

The existing literature has practical implications for those who work with middle school teachers in rural Tennessee. Administrators play a vital role in education as they impact teachers' work assignments, access to resources, and professional evaluations (Pogodzinski, 2014). The leadership and support they provide can impact teacher job satisfaction (Dou et al., 2016; Ogurlu \& Sevim, 2017; Thibodeaux et al., 2015). The findings in this study provided information administrators may find useful and could help them provide proper support for their teachers. One recommendation for administrators, as indicated by participants, is to remove the perceived disconnect between themselves and their administration by working to improve personal relationships. In addition to a disconnect from administration, teachers perceived those in higher positions in education have a greater disconnect as they have either been away from the classroom longer or have never been in the classroom. It is important for educational stakeholders at the school, district, and federal levels to relate to educators and understand the pressures and challenges they experience.

\section{Limitations}

To collect data that aligned with the purpose of understanding the lived experiences of experienced middle school educators in rural Tennessee, it was important to set delimitations. The criteria for participation in this study required teachers to have more than five years of teaching experience as this study was focused on the lived experiences of experienced educators. Rural schools are generally smaller in size and employ fewer faculty. This limited the potential population and, thus, necessitated allowing participants with five or more years of experience to be included in the study. Participants also had to teach students at the middle school level in rural Tennessee at the time of the study. The third criteria for participants required them to self-report as experiencing low job satisfaction using Spector's (1997) JSS. This study was aimed to understand the lived experiences of middle school teachers who self-reported as having 
unfavorable or doubtful perceptions of their jobs. The purpose of having participants who possessed unfavorable or doubtful perceptions of their jobs was not only to share their lived experiences, but also to gain a deeper understanding of their perceptions concerning various aspects of the teaching profession.

Although there were delimitations set in place, there were limitations present in the study that are important to address. For instance, a total of 12 participants were invited to participate in the study; however, due to inclement weather and sickness among the counties where teachers worked, several snow and sick days were issued in a short period of time. This added to teachers' stress and workload and caused two participants to withdraw from the study. Ultimately, 10 teachers participated in the study, but there was a gender bias present as there were two male teachers and eight female teachers. Another limitation to this study included the study focusing on only educators in rural Tennessee. Furthermore, rural educators in the Southeastern part of the United States were the only sample used in this study of teacher job satisfaction.

\section{Recommendations}

Teacher job satisfaction is a growing concern in education (Drummond \& Halsey, 2014; Lindqvist \& Nordanger, 2016). Teachers play an essential role in education and the future. It is important to help increase teacher retention and to provide educators the support they need. With teacher attrition on the rise and the high demand for highly qualified teachers, studies on the subject of teacher job satisfaction need to continue This study contained a total of 10 participants. Only two of the participants were male teachers. A mixed-methods study with more male teachers could be helpful in avoiding a limitation and to compare male teachers' perceptions and female teachers' perceptions of job satisfaction. This study was also focused on experienced educators. Due to teacher attrition increasing, it may be beneficial to conduct a transcendental phenomenological study to understand the lived experiences of novice educators. Furthermore, such research could provide greater insight on novice teachers' perspectives on job satisfaction and help administrators and policymakers to prevent teachers from leaving the profession early in their careers. A case study focusing on educators experiencing low job satisfaction in one rural middle school setting is recommended to understand teachers' lived experiences within a particular work environment.

Finally, there was not a great deal of information discovered within the data of this study that provided insight into the chronosystem layer of Bronfenbrenner's $(1976,1979)$ EST. A phenomenological study with a transcendental approach is recommended to focus on the chronosystem layer of the theory and how major life events in teachers' lives impact job satisfaction. This could be beneficial for administrators and policymakers in examining the workload and job-related demands placed on teachers and how major life events could impact teachers' perceptions of job satisfaction. Findings of this recommended study could also add to Bronfenbrenner's $(1976,1979)$ EST.

\section{Funding Details}

No financial incentives or grants were associated with this study.

\section{Disclosure Statement}

There were no financial interests or benefits to any author or participant in this study. 


\section{References}

Aldridge, J. M., \& Fraser, B. J. (2016). Teachers' views of their school climate and its relationship with teacher self-efficacy and job satisfaction. Learning Environments Research, 19(2), 291-307. https://doi.org/10.1007/s10984-015-9198-x

Azano, A. P., \& Stewart, T. T. (2015). Exploring place and practicing justice: Preparing pre-service teachers for success in rural schools. Journal of Research in Rural Education (Online), 30(9), 1-12.

Balwant, P. T. (2016). Socio-demographic predictors of secondary school teacher absenteeism in Trinidad. International Journal of Employment Studies, 24(1).

Banerjee, N., Stearns, E., Moller, S., \& Mickelson, R. A. (2017). Teacher job satisfaction and student achievement: The roles of teacher professional community and teacher collaboration in schools. American Journal of Education, 123(2), 203-241.

Benner, A. D., Boyle, A. E., \& Sadler, S. (2016). Parental involvement and adolescents' educational success: The roles of prior achievement and socioeconomic status. Journal of Youth and Adolescence, 45(6), 1053-1064. https://doi.org/10.1007/s10964-016-0431-4

Benoliel, P., \& Barth, A. (2017). The implications of the school's cultural attributes in the relationships between participative leadership and teacher job satisfaction and burnout. Journal of Educational Administration, 55(6), 640-656. https://doi.org/10.1108/JEA-102016-0116

Bogler, R., \& Nir, A. E. (2014). The contribution of perceived fit between job demands and abilities to teachers' commitment and job satisfaction. Educational Management Administration \& Leadership, 43(4), 541-560. https://doi.org/10.1177/1741143214535736

Bronfenbrenner, U. (1976). The experimental ecology of education (ED131025). American Educational Research Association. ERIC. https://files.eric.ed.gov/fulltext/ED131025.pdf

Bronfenbrenner, U. (1979). The ecology of human development. Harvard University Press.

Bureau of Labor Statistics. (2018). Occupational outlook handbook. Retrieved from https://www.bls.gov/ooh/education-training-and-library/middle-school-teachers.htm \#tab-3

Burns, M. K., Warmbold-Brann, K., \& Zaslofsky, A. F. (2016). Ecological systems theory in school psychology review. School Psychology Review, 44(3), 249-261. https://doi.org/10.17105/spr-15-0092.1

Cansoy, R., \& Parlar, H. (2018). Examining the relationship between school principals' instructional leadership behaviors, teacher self-efficacy, and collective teacher efficacy. International Journal of Educational Management, 32(4), 550-567. https://doi.org/10.1108/IJEM-04-2017-0089

Creswell, J. W. (2013). Qualitative inquiry \& research design: Choosing among five approaches. Sage.

Cucchiara, M. B., Rooney, E., \& Robertson-Kraft, C. (2015). "I've never seen people work so hard!" teachers' working conditions in the early stages of school turnaround. Urban Education, 50(3), 259-287.

De Klerk, E. D., Palmer, J. M., \& Modise, A. (2021). Re-prioritizing Teachers' Social Emotional Learning in Rural Schools Beyond Covid-19. Journal of Ethnic and Cultural Studies, 8(2), 68-88.

Desouky, D., \& Allam, H. (2017). Occupational stress, anxiety, and depression among Egyptian teachers. Journal of Epidemiology and Global Health, 7(3), 191-198. https://doi.org/10.1016/j.jegh.2017.06.002 
Dou, D., Devos, G., \& Valcke, M. (2016). The relationship between school autonomy gap, principal leadership, teachers' job satisfaction job satisfaction and organizational commitment. Educational Management Administration \& Leadership, 45(6), 959-977. https://doi.org/10.1177/1741143216653975

Drummond, A., \& Halsey, R. J. (2014). Rural leadership preparation associated with higher job satisfaction. Australian and International Journal of Rural Education, 24(3), 43-48. http://www.spera.asn.au/school/publications/journals/15/57

Evers, A. T., van der Heijden, B. I. J. M., Kreijns, K., \& Vermeulen, M. (2015). Job demands, job resources, and flexible competence: The mediating role of teachers' professional development at work. Journal of Career Development, 43(3), 227-243. https://doi.org/10.1177/0894845315597473

Evers, A. T., Yamkovenko, B., \& Van Amersfoort, D. (2017). How to keep teachers healthy and growing: The influence of job demands and resources. European Journal of Training and Development, 41(8), 670-686. https://doi.org/10.1108/EJTD-03-2017-0018

Ford, T. G., Van Sickle, M. E., Clark, L. V., Fazio-Brunson, M., \& Schween, D. C. (2017). Teacher self-efficacy, professional commitment, and high-stakes teacher evaluation policy in Louisiana. Educational Policy, 202-248. https://doi.org/10.1177/0895904815586855

Gius, M. (2015). A comparison of teacher job satisfaction in public and private schools. Academy of Educational Leadership Journal, 19(3), 155-164.

Gkolia, A., Belias, D., \& Koustelios, A. (2014). Teacher's job satisfaction and self-efficacy: A review. European Scientific Journal, 10(22), 321-342. https://doi.org/10.19044/esj.2014.v10n22p\%25p

Glover, T. A., Nugent, G. C., Chumney, F. L., Ihlo, T., Shapiro, E. S., Guard, K., Koziol, N., \& Bovaird, J. (2016). Investigating rural teachers' professional development, instructional knowledge, and classroom practice. Journal of Research in Rural Education, 31(3), 1-16. http://jrre.psu.edu/wp-content/uploads/2016/05/31-3.pdf

Graham, D. (2015). Collegial administrative support: Reflections from a principal at an at-risk public high school. Principal's Research Review, 10(3), 1-3. http://www.nassp.org/knowledge-center/publications/principals-research-review

Gray, C., Wilcox, G., \& Nordstokke, D. (2017). Teacher mental health, school climate, inclusive education, and student learning: A review. Canadian Psychology, 58(3), 203-210. https://doi.org/10.1037/cap0000117

Gulosino, C. A., Jones, L., \& Franceschini, L. (2016). Using the competing values framework (CVF) to examine teacher satisfaction in Tennessee schools. Planning and Changing, 47(3), 141-168.

Hos, R., Murray-Johnson, K., \& Correia, A. (2019). Cultivating capital for high school newcomers: A case study of an urban newcomer classroom. Journal of Ethnic and Cultural Studies, 6(1), 101-116.

Huang, S., Hongbiao, Y., \& Lv, L. (2019). Job characteristics and teacher well-being: The mediation of teacher self-monitoring and teacher self-efficacy. An International Journal of Experimental Educational Psychology, 1-19. https://doi.org/10.1080/01443410.2018.1543855

Im, M. H., Hughes, J. N., \& West, S. G. (2016). Effect of trajectories of friends' and parents' school involvement on adolescents' engagement and achievement. Journal of Research of Adolescents, 26(4), 963-978. https://doi.org/10.1111/jora.12247 
Johari, J., Yean Tan, F., \& Tjik Zulkarnain, Z. I. (2018). Autonomy, workload, work-life balance, and job performance among teachers. International Journal of Educational Management, 32(1), 107-120. https://doi.org/10.1108/IJEM-10-2016-0226

King, M. C. (2017). A meta-analysis of factors contributing to the job satisfaction-performance relationship. [Master's thesis, San Francisco State University]. Leonard Library ScholarWorks. http://hdl.handle.net/10211.3/196468

Kronholz, J. (2013). No substitute for a teacher: Adults' absences shortchange students. Education Next, 13(2). 16-21 https://www.educationnext.org/no-substitute-for-a-teacher/

Lindqvist, P., \& Nordanger, U. K. (2016). Already elsewhere- a study of skilled teachers' choice to leave teaching. Teacher and Teacher Education, 5, 88-97. https://doi.org/10.1016/j.tate.2015.11.010

Lindroth, J. T. (2014). Reflective journals: A review of the literature. Update: Applications of Research in Music Education, 34(1), 66-72. https://doi.org/10.1177/8755123314548046

Liu, H., \& Cheung, F. M. (2015). The role of work-family role integration in a job demandsresources model among Chinese secondary school teachers. Asian Journal of Social Psychology, 18(4), 288-298. https://doi.org/10.1111/ajsp.12103

Liu, Y., Aungsuroch, Y., \& Yunibhand, J. (2016). Job satisfaction in nursing: A concept analysis study. International Nursing Review, 63(1), 84-91. https://doi.org/10.1111/inr.12215

Lowe, G. Gray, C., Prout, P. Jefferson, S. \& Shaw, T. (2019). Still keen and committed: Piloting an instrument foridentifying positive veteran teacher. Teachers and Teaching, 25(4), 418433. https://doi.org/10.1080/13540602.2019.1621829

Mee, M., \& Haverback, H. R. (2014). Commitment, preparation, and early career frustrations: Examining future attrition of middle school teachers. American Secondary Education, 42(3), 39-51. https://www.jstor.org/stable/43694933

Moustakas, C. (1994). Phenomenological research methods. Sage.

Nand, L. (2017). Applying ecological systems theory to understand the determinants of early school leaving and second-chance education in a socioeconomically disadvantaged area in Sydney, Australia. [Doctoral dissertation, Western Sydney University]. http://researchdirect.uws.edu.au/islandora/object/uws\%3A44416/datastream/PDF/view

National Education Association (NEA). (2017). Rural schools. http://www.nea.org/home/16358.htm

Oberle, E. \& Schonert-Reichl, K. A. (2016). Stress contagion in the classroom? The link between classroom teacher burnout and morning cortisol in elementary school students. Social Science \& Medicine, 159, 30-37. https://doi.org/10.1016/j.socscimed.2016.04.031

Ogurlu, U., \& Sevim, M. N. (2017). The opinions of gifted students about leadership training. Journal of Ethnic and Cultural Studies, 4(2), 41-52.

Okeke, C. I., \& Mtyuda, P. N. (2017). Teacher job dissatisfaction: Implications for teacher sustainability and social transformation. Journal of Teacher Education for Sustainability, 19(1), 54-68. https://doi.org/10.1515/jtes-2017-0004

Parsley, D. \& Barton, R. (2015). The myth of the little red schoolhouse: Challenges and opportunities for rural school improvement. Peabody Journal of Education, 90(2), 191-193. https://doi.org/10.1080/0161956x.2015.1022108

Pogodzinski, B. (2014). Collegial support and novice teachers' perceptions of working conditions. Journal of Educational Change, 15(4), 467-489. doi:10.1007/s10833-013-9221-x

Prout, P. F., Lowe, G. M., Gray, C. C, \& Jefferson, S. (2019). An elixir for veteran teachers: The power of social connections in keeping these teachers passionate and enthusiastic in their 
work. The Qualitative Report, 24(9), 2244-2258. https://nsuworks.nova.edu/tqr/vol24/iss $9 / 10$

Przybylska, I. (2016). Emotional intelligence and burnout in teaching profession. The New Educational Review, 43(1), 41-52. https://doi.org/10.15804/tner.2016.43.1.03

Rankin, J. (2017). First aid for teacher burnout. Routledge.

Rosa, E. M. \& Tudge, J. (2013). Urie Bronfenbrenner's theory of human development: Its evolution from ecology to bioecology. Journal of Family Theory \& Review, 5(4). https://doi.org/10/1111/jftr.12022

Sahito, Z., \& Vaisanen, P. (2017). Factors affecting job satisfaction of teacher educators: Empirical evidence from the universities of Sindh Providence of Pakistan. Journal of Teacher Education and Educators, 6(1), 5-30. https://doi.org/10.17507/j1tr.0905.04

Sapkova, A. (2014). System of mathematics teachers' beliefs about effective teaching/learning and practice as a complex adaptive system. Journal of Studies in Education, 4(3), 15-31. http://dx.doi.org/10.5296/jse.v4i3.5119

Sezgin, F., Kosar, S., Kiline, A. C., \& Ogdem, Z. (2014). Teacher absenteeism in Turkish primary schools: A qualitative perspective from school principals. International Online Journal of Educational Sciences, 6(3), 612-625. https://doi.org/10.15345/iojes.2014.03.010

Shapira-Lishchinsky, O., \& Raftar-Ozery, T. (2016). Leadership, absenteeism acceptance, and ethical climate as predictors of teachers' absence and citizenship behaviors. Educational Management Administration \& Leadership, 46(3). 491-510. https://doi.org/10.1177/1741143216665841

Skaalvik, E. M., \& Skaalvik, S. (2010). Teacher self-efficacy and teacher burnout: A study of relations. Teaching and Teacher Education, 26(4), 1059-1069. https://doi.org/10.1016/j.tate.2009.11.001

Skaalvik, E. M., \& Skaalvik, S. (2015). Job satisfaction, stress, and coping strategies in the teaching profession: What do teachers say? International Education Studies, 8(3), 181-192. https://doi.org/10.5539/ies.v8n3p181

Skaalvik, E. M., \& Skaalvik, S. (2018). Job demands and job resources as predictors of teacher motivation and well-being. Social Psychology of Education, 21(5), 1251-1275. https://doi.org/10.1007/s11218-018-9464-8

Smith, P. S., Hayes, M. L., \& Lyons, K. M. (2017). The ecology of instructional teacher leadership. The Journal of Mathematical Behavior, 46, 267-288. https://doi.org/10.1016/j.jmathb.2016.12.005

Spector, P. E. (1997). Job satisfaction: Application, assessment, courses, and consequences. Sage.

Spector, P. E. (1999). Instructions for scoring the job satisfaction survey, JSS. University of South Florida. http://shell.cas.usf.edu/ pspector/scales/jssscore.html

Sroufe, L. A. (2013). The promise of developmental psychopathology: Past and present. Development and Psychopathology, 25(4), 1215-1224. https://doi.org/10.1017/S0954579413000576

Tang, Y., He, W., Liu, L., \& Li, Q. (2018). Beyond the paycheck: Chinese rural teacher well-being and the impact of professional learning and local community engagement. Teachers and Teaching, 24(7), 825-839. https://doi.org/10.1080/13540602.2018.1470972

Tennessee Education Association (TEA). (2019). Salary data. https://teateachers.org/salary-data

Thibodeaux, A. K., Labat, M. B., Lee, D. E., \& Labat, C. A. (2015). The effects of leadership and high-stakes testing on teacher retention. Academy of Educational Leadership Journal, 19(1), 227-236. 
Todd-Gibson, C. (2017). An examination of how middle school science teachers conduct collaborative inquiry and reflection about students' conceptual understanding. Contemporary Issues in Education Research (Online), 10(2), 169-178. https://doi.org/10.19030/cier.v10i2.9933

Troesch, L. M. \& Bauer, C. E. (2017). Second career teachers: Job satisfaction, job stress, and the role of self-efficacy. Teaching \& Teacher Education, 67, 389-398. https://doi.org/10.1016/j.tate.2017.07.006

Waterman, S. S. (2013). Differentiating assessment in middle and high school mathematics and science. Routledge.

Wieczorek, D., \& Manard, C. (2018). Instructional leadership challenges and practices of novice principals in rural schools. Journal of Research in Rural Education, 34(2), 1-21. http://jrre.psu.edu/wp-content/uploads/2018/03/34-2.pdf

Woodyatt, C. R., Finneran, C. A., \& Stephenson, R. (2016). In-person versus online focus group discussions: A comparative analysis of data quality. Qualitative Health Research, 26(6), 741-749. https://doi.org/10.1177/1049732316631510

Yu, X., Wang, P., Zhai, X., Dai, H., \& Yang, Q. (2015). The effect of work stress on job burnout among teachers: The mediating role of self-efficacy. Social Indicators Research, 122(3), 701-708. https://doi.org/10.1007/s11205-014-0716-5

Zuckerman, S. J., Campbell Wilcox, K., Schiller, K. S., \& Durand, F. T. (2018). Absorptive capacity in rural schools: Bending not breaking during disruptive innovation implementation. In E. McHenry-Sorber \& D. Hall (Eds.), The diversity of rural educational leadership [Special issue]. Journal of Research in Rural Education, 34(3), 1-27. http://jrre.psu.edu/wp-content/uploads/2018/03/34-3.pdf

\section{Notes on Contributors}

Shayla D. Carew, EdD, is a middle school English teacher in the public schools of Tennessee. She has served on the Tennessee Educator Recognition Advisory Council.

Timothy R. Nelson, EdD, is a middle school math teacher in the public schools of South Carolina. In addition to his work there, he teaches graduate courses on research methodology, educational statistics, and professional publication for Liberty University.

Manuscript received January 31, 2021

Final revision received March 20, 2021

Accepted March 20, 2021 